\title{
Error Correction Strategies for the Classroom Oral Proficiency Used By Jordanian Teachers at Secondary Level
}

\author{
Abeer Al-Ghazo \\ Assistant Professor, TEFL, Ajloun National University \\ Ajloun, Jordan \\ E-mail: fares.abeer@yahoo.com
}

Received: August 21, 2016 Accepted: September 05, 2016 Published: October 02, 2016

doi:10.5296/ijld.v6i3.10038 URL: http://dx.doi.org/10.5296/ ijld.v6i3. 10038

\begin{abstract}
The aim of the present study was to explore the Jordanian EFL teachers' error correction strategies for the classroom oral proficiency at secondary level. For the purpose of obtaining information needed to achieve the objectives of the study, the researchers used the Teacher's Preference Elicitation Questionnaire. This Questionnaire was adapted from Michael (2007) to elicit the types of oral corrective feedback that teachers prefer to use to correct their students' oral errors, grammatical and pronunciation errors. The questionnaire was administered to 40 teachers. The findings revealed that the teachers used all types of oral corrective feedback with a grand mean of (3.29) .Meta linguistic feedback, recast, elicitation, instructions and questioning (Peer-correction) were reported to be the most used strategies of oral corrective feedback.
\end{abstract}

Keywords: Oral error correction, Teachers, Students, Correction strategies. 


\section{Introduction}

The development of accuracy should be encouraged. As learners produce (speaking and writing) language, instruction and feedback can help facilitate the progression of their skills $\mathrm{f}$ toward more precise and coherent language use". (Omaggio, 2001)

In the field of EFL, there have been some efforts to study the corrective feedback in English as Foreign Language (EFL) classrooms. EFL students' oral proficiency should be corrected. Correcting students' oral language errors is a complex aspect of foreign language teaching. According to Lennon (1991) an error is "a linguistic form or combination of forms which in the same context and under similar conditions of production would, be produced by the speakers' native speakers' counterparts".

When deciding whether an error should be corrected, teacher should have into account many factors such as the type of error (e.g., pronunciation, word choice, sentence structure), if the error $\mathrm{s}$ interfere with the meaning of the text, the objectives of the activities, the complexity of the message in relationship to the student's variables such as their attitudes, level of proficiency, and their level of confidence. It is very essential to convey the message that positive oral correction plays an important role in encouraging students' learning and is considered an effective tool for facilitating the process of acquisition and learning language. Swain's (1995) claimed that correcting errors helps the students learn better, "whether the feedback is explicit or implicit (p. 48)".

Error correction (EC) helps teacher to determine their classroom teaching practices and their teaching methodology to improve their students' oral proficiency. To measure the learners' level of oral proficiency in the language, they should be assessed regularly to suggest proper solution, and then enhance their performance in learning the English language. EC is considered to be one of the important parts of teaching/ learning process. Lightbown and Spada (1999) pointed out the usefulness of EC. EC encourage the students to learn the language and continue their communication in the target language (Ancker, 2000; Burt, 1975; DeKeyser, 1993; Hendrickson, 1978; McDonough, 2005; Schmidt, 1990). Teachers need to develop a whole range of feedback mechanisms and determine when and how to use them to foster optimal growth in proficiency. Long (1996) has also confirmed that feedback helps learning a second or a foreign language. Schulz (1996) found that $80 \%$ of the students surveyed in eight languages at various levels of instructions felt that grammer instructions were essential and $90 \%$ of students stated that they would like to have their spoken errors corrected. The findings from most of the researchers indicated the effective role of EC as a major aspect in educational systems. There have been numerous investigations to find out which types of EC employed by teachers are more useful.

Lyster and Ranta indicate different types of error treatment, or corrective feedback, with student responses to that feedback, or "learner uptake" (1997, p. 40). They were interested in finding what types of corrective feedback that lead students to correct their own errors with an eye toward grammatical accuracy and lexical precision within a meaningful communicative context. They identified six types of feedback teachers used explicit correction: indicating that the student's utterance was incorrect, the teacher provides the 
correct form. Recast: indicating that the student's utterance was incorrect, the teacher implicitly reformulates the student's error, or provides the correction. Clarification request : the teacher indicates that the message has not been understood or that the student's utterance contained some kind of mistake and that a repetition or a reformulation is required. Met linguistic clues: the teacher provides comments or information related to the formation of the student's utterance Elicitation. The teacher directly elicits the correct form from the student by asking many questions. Repetition: The teacher repeats the student's error and tries to draw student's attention to it (pp.46-48).

It is clear that the use of error correction in the classroom can provide an optimal and effective environment for EFL learning. By applying these corrected strategies, students are provided with more opportunities to accomplish their tasks and then to obtain a sense of achievement effectively. The main question here is whether our teachers should be allowed or handled wisely using common correction strategies or techniques to provide the students with feedback of their oral errors.

Numerous studies have shown the effectiveness of oral corrective strategies for the classroom oral proficiency used by teachers.

Salikin (2001, p. 2) did a study with the junior students at the English Department in Jember University .He found that the participants felt positive about error correction and expressed that they not only welcomed feedback from teachers, but also from their peers, and also reported that that they did not prefer to be interrupted very often. The students preferred their pronunciation mistakes to be corrected rather than their grammar mistakes

Chen (2005) conducted a research with three English instructors teaching speaking classes in Taiwan in order to analyze effective feedback and error treatment. The results mentioned by the subjects that they did not prefer to correct most of the learners' errors as learners had negative feelings, such as embarrassment and anxiety when they were corrected in class. Furthermore, the participants seemed to have a consensus that errors were natural parts of learning and need not be corrected every time, and they all agreed that errors of pronunciation were common among learners and such errors should not be ignored.

Katayama (2007, p. 289) did a research about the attitudes of Japanese students in the US towards correction of errors and found that the students preferred the correction made by the teacher and enjoyed having their pragmatic errors corrected. They also preferred getting cues from their teachers so that they can correct their own errors.

Kavaliauskiene et al. (2009) focused on students' attitudes towards correction, and the results showed that although students preferred error correction for their writing performance, they did not like being corrected during speaking activities.

Lin (2009) investigated the types of oral corrective feedback that teachers used in low, intermediate, and advanced level speaking classrooms using Lyster and Rantaees (1997) model. He involved participants from ESL program at a Southern California State University. The results showed that lower level students were corrected by their teachers more than the higher level students and that recasts were the most frequent used types 
Tabatabaei and Banitalebi (2011) investigated the most frequent type of oral corrective feedback techniques used by L2 Iranian teachers in L2 reading comprehension classes in an Iranian language institute. They focused on explicit correction, recast, clarification request, meta linguistic feedback, elicitation, and repetition. They found that explicit correction was the most frequent feedback technique used by teachers and elicitation was the second one (49\% \& 19\%, respectively).

Al- faki and Siddiek (2013) aimed to elicit the oral corrective feedback strategies were used by teachers in Oman. The paper discussed the results of data collected by using three instruments: a teacher's preferences elicitation instrument, a student's preferences elicitation instrument, and a classroom observation checklist. Then the results were processed to test these hypotheses that: Teachers of English at C2 \& PB levels of boys Educational System in Oman use different types of oral correction techniques. It was also hypothesized that there would be a significant difference between these teachers' attitudes about oral corrective feedback and their actual practice. In addition to that, students at C2 and PB would expect specific oral corrective feedback approaches from their teachers. The data was processed were proved to be positive.

Yasemin Kırkgöz Çukurova et al (2015) investigate CF types used in primary classrooms in Turkey, where English is taught as a foreign language and a compulsory part of the national curriculum. 36 teachers working with students of various grades in 20 state primary schools in Turkey participated in the study. Throughout a semester, EFL classes assigned to these teachers were video-recorded and transcribed to investigate what types of corrective feedback were mostly used by teachers in response to learners' spoken errors and which leaded to most uptakes in the learners at stake. The study has indicated that all types of corrective feedback were used by the teachers to help students overcome errors they made in classes of various grades and that explicit correction was the most and peer correction was the least frequently used CF types in all four grades.

When we have a look at the research studies on error correction, we can see that it has been mostly the written errors, whereas oral errors, that researcher tended to focus on usually seem to have had less concern. The main reason behind this is that the oral corrective strategies seem to offer a more challenging task for researchers as well as teachers. Therefore the main question here is how oral errors should be treated in the Jordanian EFL context needs to be investigated in order to handle students' errors more effectively

\section{Statement of the Problem}

In the field of education system in Jordan, there are many problems associated with error correction in the EFL classroom. For example, every student wants to improve his/her accuracy but not every student likes being corrected. Another common problem is that students and teachers often disagree on the amount of error correction that there should be in class. In addition, there much more difficult task of getting the amount of error correction refer to many variables such as individual level, age group, nationality, personality type, learning style etc. It is important to recognize the fact that exploring the teacher's error correction strategies are important means of understanding classroom practices and oral 
performance with a view to improving them for better teaching process.

The researcher believes that there are many reasons stand behind students' poor oral proficiency. I think that most of the EFL teachers don't vary the strategies they used to assess oral comprehension. They may concentrate on assessing students' comprehension at the word and sentence levels rather than concentrating on their oral or speaking comprehension. It will be better to vary in the methods and strategies our teachers should use in assessing their students' oral proficiency to improve the accuracy and quality of their spoken language use

\section{Purpose of the Study}

This study aimed at exploring the Jordanian EFL teachers' error correction strategies for the classroom oral proficiency at secondary level

\section{Significance of the Study}

Since there is a profound need to explore Jordanian public school teachers' error correction strategies for the classroom to develop their students' oral proficiency at secondary level, it is hoped that the findings of the study may provide teachers with insights into their students' oral performances and achievement in the classroom. In addition, this study will also shed light on the importance of changing teacher's attitudes toward teaching English, because one of the main requirements of professionalized teaching involves changes in the attitudes of teachers. Moreover, this study should open venues for further research to share experience with EFL teachers to provide constructive feedback on their language development

\section{Questions of the study}

This study attempts to answer the following question

-What are the main error correction strategies used by teachers at secondary level to develop the classroom oral proficiency?

\section{Definition of terms}

6.1. Elicitation Feedback: attempting to elicit a correct utterance from a learner, such as a leader where the learner would merely fill in the blank with the correct phrase, or a specific question to elicit a particular response (Lyster \& Ranta, 1997)

6.2. Recast: The restating of a learner's utterance, but without the error, thus demonstrating the correct form (Lyster \& Ranta, 1997).

6.3. Repetition: Feedback whereby the teacher emphatically follows up the feedback, including responses with repair of the non-target items as well as utterances still in need of repair (Lyster \& Ranta, 1997).

\section{Method of the Study}

This study aimed at finding out the error correction strategies for the classroom oral proficiency used by teachers at secondary level. This section presents the methods and procedures that were used to conduct this study. It includes participants of the study, research 
instruments, procedures, statistical analysis, data collection and data analysis procedures

\subsection{Participants of the study}

Shank (2002) indicates that selection of study participants depends on research topic, questions, availability, and other study characteristics. Due to the purpose of this study, the participants of the study were 40 female EFL teachers. They were purposefully chosen from the schools in Ajloun Directorate of Education for the academic year 2015/2016.

The generalization of the results of the study is limited by these factors:

1- This study is conducted on female EFL Jordanian teachers in Ajloun Directorate of Education in the academic year 2015/2016. Therefore, the generalizability of the results of this study is applicable to similar populations only.

2- The number of the participants of the study (40 teachers) is relatively small.

\subsection{Instruments of the study}

For the purpose of obtaining information needed to achieve the objectives of the study, the researchers used the Teacher's Preference Elicitation Questionnaire. This Questionnaire was adapted from Michael (2007) to elicit the types of oral corrective feedback that teachers use to correct their students' oral errors, grammatical and pronunciation errors (see appendix A)

\subsection{Validity and Reliability of the Instruments}

To guarantee the validity of the questionnaire, a number of TEFL specialists in Jordanian universities will assess it. The reliability of the questionnaire was measured by administering 20 ones to 20 female and male teachers who were chosen from outside the participants of the study for the second time after two weeks from collecting the questionnaires which were administrated earlier. Pearson correlation was computed of the tool as a whole, using Test-Retest strategy (Stability index), it was 0.85. The internal consistency coefficient was also computed using Cronbach Alpha, it was 0.89. This result was considered satisfactory to use the questionnaire to collect the needed data.

\section{The Results and Their Discussion}

To answer the first question, the researchers calculated means for error correction strategies for the classroom oral proficiency used by teachers at secondary level. Table 1 displays the solicited responses of the teachers on the frequency of error correction. 


\section{Ml Macrothink}

International Journal of Learning and Development ISSN 2164-4063 2016, Vol. 6, No. 3

Table 1: error correction strategies for the classroom oral proficiency used by teachers at secondary level

\begin{tabular}{|l|l|l|}
\hline Techniques & Means & Description \\
\hline Recast & 4.25 & Very good \\
\hline Explicit Correction. & 3.48 & Very good \\
\hline Repetition of Error & 3.48 & good \\
\hline Elicitation "fill in the blank"ee. & 3.72 & good \\
\hline Metalingustic Feedback. & 3.99 & Very good \\
\hline Clarification Request ce & 3.68 & good \\
\hline Denial. & 2.34 & acceptance \\
\hline Questioning (Peer Correction & 3.59 & good \\
\hline Questioning (Self Correction) & 2.94 & acceptance \\
\hline Ignorance & 1.49 & poor \\
\hline Total & 3.296 & \\
\hline
\end{tabular}

As Table (1) reveals, teachers used all types of oral corrective feedback with a mean of (3.29). Meta linguistic feedback, recast, elicitation, instructions and questioning (Peer-correction) were reported to be the most used types of oral corrective feedback.). We can notice the big gap between the use of denial and ignorance and other strategies. The usage of recast by teachers might be that strategy may encourage slow learners to continue speaking without explicitly correcting their errors. This finding is similar to the study of Lyster and Ranta (1997) who found that the teachers in their study provided corrective feedback using recasts over half of the time $(55 \%)$.

Requesting and questioning (Peer-correction) were also highly used as they had means of (3.68) and (3.59) respectively. This could focus on teachers' desire to increase students' participation by using request and questioning (peer-correction). By this way Learners learn how to correct each other errors in face-to-face interaction in a safe environment. As the table shows, self correction, ignorance and denial strategies have the lowest usage in this category. The low usage of these strategies could be attributed to teachers' desire not to does any correction when the student makes an error, although they are supposed to encourage their 
students to be more independent learners and try to repair their errors. This is in line with the studies of Lyster \& Ranta (1997) and Panova and Lyster (2002). They found that denial and ignorance were rarely used by teachers.

It would be fair to suggest that the teacher did not neglect any of the errors and treated errors immediately using different strategies.

As for the error correction types, it would be true to suggest that contrary to Lyster and Ranta's findings mentioned earlier, recast was the least preferred type used to correct both grammar and pronunciation errors while repetition was the most common for both errors. Repetition also seems to lead to successful uptake with two self- and two peer-corrections

\section{Conclusion}

"To err is not only human; it is an integral part of language acquisition" Anabel Gonzalez in Education Work Teacher

It can be noticed that error correction can be one of the hardest aspects of teaching to manage for both new and experienced teachers because they have to ask themselves many questions such as: When is error correction needed? Should I let my students talk, or interject every time they make a mistake? Do I correct everything? What are those areas? How do I correct errors without undermining my students' confidence?

In this study, the main focus is on the corrective feedback strategies a teacher provides after a student oral error. Based on the findings of the study, teachers favor corrections of language errors; and they did not neglect any of the errors and treated errors immediately using different strategies. These strategies give teachers clear pictures about their classroom practices on how they correct their students' oral errors .On other words, it enables teachers to arrive at their own judgments as to what works and what does not work in their classrooms. Moreover, it can narrow the gap between teacher's imagined view of their own teaching and reality.

\section{References}

Ancker, W. (2000). Errors and Corrective Feedback: Updated Theory and Classroom Practice. English Teaching Forum, 38 (4), 20-25.

Al-Faki,I . Siddiek,A. (2013). Techniques Used by Teachers in Correcting Students ${ }^{\text {ee }}$ Oral Errors in an Omani Boys School. Theory and Practice in Language Studies, 3, (10), 1770-1783.

Burt, M. K. (1975). Error analysis in the adult ESL classroom. TESOL Quarterly, 53- 63.

Chen, C. J. (2005). Effective feedback and error treatment: EFL Guidance for Academic Leaders (Unpublished doctoral dissertation). The University of Montana, the USA.

DeKeyser, R. M. (1993). The effect of error correction on L2 grammar knowledge and oral proficiency. The Modern Language Journal, 77(4), 501-514 


\section{Macrothink}

International Journal of Learning and Development

ISSN 2164-4063

2016, Vol. 6, No. 3

Hendrickson, J. M. (1984). The treatment of error in writing work. In S. McKay (Ed.), Composing in a second language (145-159). Rowley MA: Newbury House

Katayama, A. (2006). Perceptions of JFL students toward correction of oral errors. In Bradford-Watts, K., Ikeguchi, C., \& Swanson, M. (Eds.) JALT2005 Conference Proceedings, Tokyo: JALT, 1248-1264

Katayama, A. (2007). Japanese EFL students' preferences toward correction of classroom oral errors. Asian EFL Journal, 9(4), 289-305.

Kavaliauskiene, G., Kaminskiene, L., \& Anusiene, L. (2009). Classroom Practice: Error Correction at Tertiary Level. Kalbu studijos, 14, 1-9.

Lennon, P.. 1991. "Error: some problems of definition and identification", in Applied Linguistic, vol. 12, num. 2, Oxford, pp. 180-195.

Lightbown, P. \& Spada, N. (1999). Instruction, first language influence, and developmental readiness in second language acquisition. The Modern Language Journal, 83(1), 1-22.

Lin, H. (2009). Patterns of Corrective Feedback and Learner Uptake in ESL Low, Intermediate, and Advanced Level Speaking Classrooms (PHD Dissertation). Alliant International University, San Diego.

Long, M. (1996). The role of the linguistic environment in second language acquisition. In Ritchie, W. \& Bhatia, T. (eds.), Handbook of Research on Language Acquisition, 413-468. San Diego: Academic Press.

Lyster, R. \& Ranta, L. (1997). Corrective feedback and learner uptake: Negotiation of form in communicative classrooms. Studies in Second Language Acquisition, 19, 37-66.

McDonough, K. (2005). Identifying the impact of negative feedback and learners' responses on ESL question development. Studies in Second Language Acquisition, 27(1), 70-103.

Omaggio-Hadley, Alice. (2001). Teaching language in context (3rd ed.). Boston: Heinle \& Heinle

Panova, I. \& Lyster, R. (2002). Patterns of corrective feedback and uptake in an adult ESL classroom. TESOL Quarterly, 36(4), 573-595

Schulz, R. (1996). Focus on form in the foreign language classroom: students ${ }^{\text {ee }}$ and teachers ${ }^{\text {ee }}$ views on error correction and the role of grammar. Foreign Language Annals, 29 (3), 343-364.

Schmidt, R. (1990). The role of consciousness in second language learning. Applied Linguistics, 11(2), 129-158.

Swain, M. (1995). The output hypothesis: Just speaking and writing are not enough. The Canadian Modern Language Review, 50(1), 158-164

Salikin, H. (2001). Learner's perception of oral error correction: An interpretive study. JIBS (Jurnal Ilmn Bahasa dan Sastra), 1(2). 


\section{Macrothink \\ International Journal of Learning and Development \\ ISSN 2164-4063 2016, Vol. 6, No. 3}

Shank, G.D. (2002).Qualitative research, a personal skills approach. Upper Saddle River, New Jersey: Pearson Education, Inc.

Tabatabaei, O. \& Banitalebi, A. (2011). Feedback Strategies in Foreign Language Reading Classes. Asian Culture and History, 3(2), 59-70

Yasemin Kırkgöz Çukurova et al (2015). Corrective Feedback in Primary EFL Classrooms in Turkey. American International Journal of Social Science 4(3).90-101. 


\section{Macrothink}

International Journal of Learning and Development

ISSN 2164-4063

2016, Vol. 6, No. 3

Appendix: Error correction strategies for the classroom oral proficiency used by teachers at secondary level

$4=$ very helpful $3=$ helpful $2=$ moderately helpful $1=$ not helpful $0=$ not helpful at all

\begin{tabular}{|c|c|c|c|c|c|c|c|c|}
\hline & $\begin{array}{l}\text { Oral } \\
\text { Corrective } \\
\text { Feedback } \\
\text { Type }\end{array}$ & Definition & $\begin{array}{l}\text { Teacher } \\
\text { Response }\end{array}$ & $4=$ & 3 & 2 & 1 & 0 \\
\hline $1-$ & Recast & $\begin{array}{l}\text { The teacher repeats what } \\
\text { the learner has said } \\
\text { replacing the error }\end{array}$ & $\begin{array}{l}\text { "You have been } \\
\text { to Muscatecee }\end{array}$ & & & & & \\
\hline 2 & $\begin{array}{l}\text { Explicit } \\
\text { Correction. }\end{array}$ & $\begin{array}{l}\text { The teacher explicitly } \\
\text { provides the learners } \\
\text { with the correct form }\end{array}$ & $\begin{array}{l}\text { You should say } \\
\text { „have not ,hase }\end{array}$ & & & & & \\
\hline 3 & $\begin{array}{l}\text { Repetition of } \\
\text { Error }\end{array}$ & $\begin{array}{l}\text { The teacher repeats the } \\
\text { learner's error in } \\
\text { isolation, in most cases, } \\
\text { teachers adjust their } \\
\text { intonation so as to } \\
\text { highlight the error. }\end{array}$ & $\begin{array}{l}\text { "I has been to } \\
\text { Muscat }^{\text {eeee }} \\
\text { stressing ,hasee }\end{array}$ & & & & & \\
\hline 4 & $\begin{array}{l}\text { Elicitation } \\
\text { "fill in the } \\
\text { blank"eee. }^{\text {cece }}\end{array}$ & $\begin{array}{l}\text { Teachers provide a } \\
\text { sentence and } \\
\text { strategically pause to } \\
\text { allow students to }\end{array}$ & ${ }^{e e} \mathrm{I} \ldots{ }^{e}$ & & & & & \\
\hline 5 & $\begin{array}{l}\text { Metalingustic } \\
\text { Feedback. }\end{array}$ & $\begin{array}{l}\text { The teacher provides, } \\
\text { information, or } \\
\text { questions related to an } \\
\text { error the student has } \\
\text { made without explicitly } \\
\text { providing the correct } \\
\text { form }\end{array}$ & $\begin{array}{l}\text { "You can't say } \\
\text { „has }{ }^{\text {"e. }} \text { We use } \\
\text { „have }{ }^{\text {ee }} \text { with the } \\
\text { pronoun Ieee }\end{array}$ & & & & & \\
\hline 6 & $\begin{array}{l}\text { Clarification } \\
\text { Request }^{\circ e}\end{array}$ & $\begin{array}{l}\text { The teacher asks for } \\
\text { repetition } \\
\text { reformulation of what } \\
\text { the learner has said. }\end{array}$ & $\begin{array}{l}{ }^{e e} \mathrm{Do} \\
\text { mean...? }\end{array}$ & & & & & \\
\hline
\end{tabular}




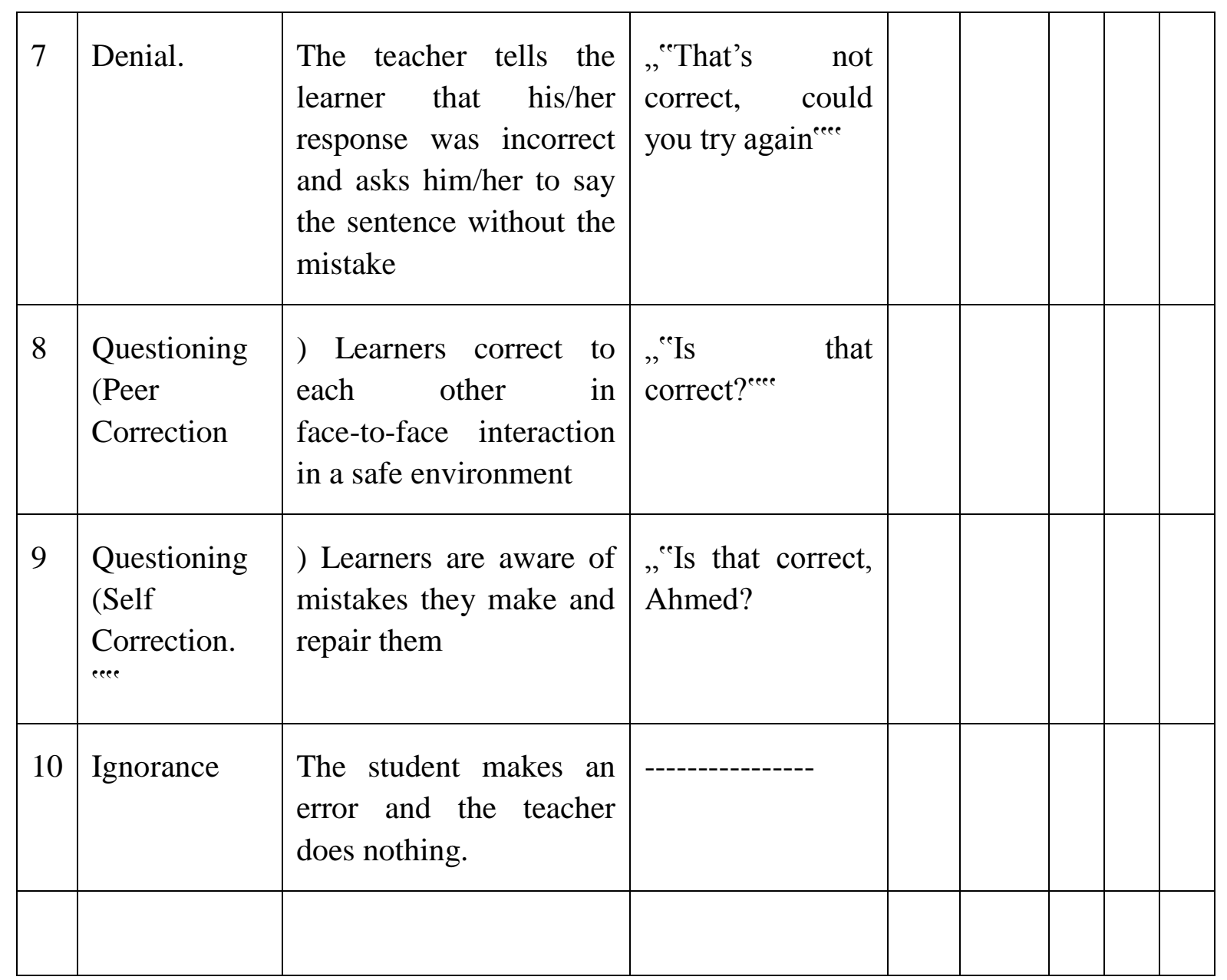

\section{Copyright Disclaimer}

Copyright for this article is retained by the author(s), with first publication rights granted to the journal.

This is an open-access article distributed under the terms and conditions of the Creative Commons Attribution license (http://creativecommons.org/licenses/by/3.0/). 